\title{
[10]
}

\section{Bar Yohai, Mystic: The Creative Persona and His Pilgrimage}

\author{
Edith Turner
}

The existence of a creative persona may involve a root metaphor embodied in a string of other individuals living in eras prior or subsequent to the persona in question. Rabbi Shimon Bar Yohai-as Moroccan Jews call him-was a second-century saint revered by the Sephardim and Hasids. The root metaphor he represents is zohar, meaning splendor or enlightenment. Popular belief attributes to Rabbi Shimon Bar Yohai the authorship of The Zohar, the renowned Kabbalistic text of Jewish mysticism. Bar Yohai, identified with The Zohar, stands at the head of a series of ancient Hebrew personages touched by the divine, starting with Enoch in the Bible (who became the angel Metatron) and continuing to Abraham and others down the ages, eventually focusing in the nodal point of Bar Yohai. In the other direction, forward in history from Bar Yohai, extends an equal string of personages up to the present, including great Hasids such as the Lubavitcher Rebbe of New York and many others, as well as the crowds of IsraeliMoroccan Jews who visit Bar Yohai's shrine at Meron in Israel on pilgrimage. The transformation of Bar Yohai into a legendary figure, the role of his visionary thought in Jewish ritual, and his present-day interaction with his devotees in dreams and their subsequent transformation show him to be an "allegorical type." Certain

This essay is dedicated to the memory of Barbara Myerhoff. 
persons in a society take on, often willy-nilly, an allegorical role, and become a type that speaks to the society or to the outside world on behalf of that society: in other words, an agent of reflexivity, a particular kind of performer. Smadar Lavie (1986: 143-44), who first proposed the concept of the allegorical type, wrote, "They appear in solo performances on the societal stage in phases of transition, when [the society asks itself] whether it exists, and on what level of organization it does so. The types bridge the geopolitical paradoxes of the present and traditional forms and figures of the past. In this manner they provide sets of specific answers to existential ... dilemmas which arise in the course of everyday life... . By entering into the inconsistent social situation with an allegorical experience, he or she reconstructs the thematic meaning of the social context. In this manner the person/persona is able to eliminate open-ended discontinuity and to transmute the paradoxes of ... precarious reality into an allegory... linked to the immortality of tradition"' (p. 143; see also Handelman 1981; Handelman and Bruce Kapferer 1980).

In his role as creative persona slowly maturing through history, the figure of Bar Yohai has become in effect an allegorical type, but he is also known on the pilgrimage simply as "the zaddik." A zaddik, defined as a righteous or saintly person, is commonly but not invariably a great scholar of the scriptures. Rabbi Shimon Bar Yohai was a scholar par excellence, and, according to tradition, a saint of great power. A tradition of zaddiks penning or studying visionary texts exists in Judaism and also to a certain extent in Islam. In the West the thaumaturgical power of sanctity is linked in believers' minds with prayer and selfsacrifice, hardly ever with biblical scholarship. Not so with the scholarly zaddiks, saints whose tombs often became the source of healing miracles. Thus, during the great folk pilgrimage of Bar Yohai, when Victor Turner and I arrived at Meron in 1983 to conduct research with fourteen scholars in anthropology, folklore, psychology, and history, ${ }^{2}$ we were able to celebrate a "scholar's holiday" (a term that Barbara Myerhoff delighted to use) for ourselves at the shrine of the saintly scholar.

Little is known about Bar Yohai's life. According to historical records, he was famous as a scholar and a patriot who opposed the Romans' occupation of Israel. He lived for twelve years in a cave, hidden from the Roman forces sent out to destroy him (Shokeid 1974: 75). Bar Yohai seems to have been content to occupy himself with studying the scriptures and, according to an unsubstantiated but strong tradi- 
tion, with writing the sublime book-a scripture in itself-The Zohar, the Book of Light. Be that as it may, Bar Yohai was known to have retreated from the violence of political power, from what was truly an "inconsistent social situation," that is, the era after the fall of Jerusalem. The liminality of his situation in the cave was well-nigh total. He was a scholar in an age of military power, in refuge on the northern frontier of Galilee, in the mountains halfway up from the earth, a member of the mystical tradition of Judaism and not the legal tradition; and his sanctity resulted in miracles, outside of the natural. (The pilgrimages to his shrine in later ages also showed strong liminal features.)

Bar Yohai not only received inspiration himself but was taken over by his society and was shaped, by means of legendary accretions, into a source of meaning for it, a mirror for it. He therefore possessed more than charisma, a characteristic of certain well-attested historical personages; he held strong allegorical and affective value for almost two millennia.

The zaddik's life, his reputed authorship of The Zohar with its particular message to the Diaspora about the "ingathering of the scattered sparks of God's light," and the history of his cultus in the ages long after his death, tell the following story. First the rabbi himself receives inspiration; in later ages he is taken over by his society, especially through the agency of Moses de Leon in the Middle Ages, whose Zohar is the only version we have; then the ideas in it, fertile with the call to an ingathering of the sparks, reach the Diaspora; there is an immediate response to The Zohar among Jews scattered over the world, which, later still, culminates in the return of the Jews to Israel. For many Jews Bar Yohai is the greatest of the scholars: it cannot be denied that the pilgrimage to his shrine is the largest in Israel, leaving devotion to the tomb of Moses far behind.

In my discussion below, I trace the antecedents and the continuation of his legend; mark his place in the story, including his own root paradigms and the ones he or Moses de Leon created; show his effects on Judaism in different stages of history; and demonstrate an actual chain of personas, each link resonating with the same creative theme.

For believers, the human root paradigm from which Bar Yohai and The Zohar, the Book of Light grows is "the visionary man." (Other translations of Zohar are "mystical perception," or "enlightened state of being.") Bar Yohai's roots extend far back in time. He undoubtedly shared the interest that scholars of his era showed in their past, for 
whom "the first chapter of Ezekiel, the vision of God's throne-chariot (the 'Merkabah') was among the favorite subjects of discussion and interpretation, which it was apparently considered inadvisable to make public" (Scholem 1961: 42). Ezekiel himself saw his vision at the bitter time of the Babylonian captivity, 590 B.C.E. Before Ezekiel, never forgotten, was the figure of Elijah, who was taken up to heaven in a chariot. And before Elijah, Moses saw God in the burning bush, a major symbol of divine light. (Many believers say Bar Yohai is the reembodiment of Moses.) Before Moses there was Abraham, who according to the Kabbalah represented the stage of love balanced with rigor-two branches, one on each side of the world tree or sephirot, the mystic diagram of the Kabbalah. And way before, in a kind of glowing mythical age of angels and heavenly wisdom, Enoch lived with God and was "translated" at his life's end; that is, he never saw death but was transformed into the angel Metatron, ablaze with fiery torches. All this was recorded by the Merkabah mystics, the mystics of the chariot-the chariot being the vehicle of religious experience.

Bar Yohai, other mystics such as the Rabbi Akiba ben Joseph, and scholars such as the second Hillel were said to have inhabited the general region of Sefat and Meron. Like many authors of books in the Bible, they are said to have ascribed what they wrote to previous sages. They did so in awe of the numinous subject matter. And they hid the texts carefully. There is dispute about the accuracy of the legends of their doings. It is probable that some extraordinary book of mysticism was written, but owing to the secrecy, no book, no hard facts can be found. The tradition of the location of Bar Yohai's tomb at Meron is also in dispute-though certainly not among pilgrims; they are sure. "Hiddenness" enters the story continually and is the despair of the textual scholar, but it may be our meat and drink.

What followed in later centuries makes the desperate secrecy of the Jews understandable. To read what the Crusaders did in Jerusalem in 1099 makes one's blood run cold. These long-frustrated and selfrighteous men, at their final successful capture of Jerusalem, strode through the city "red to the armpits" on one of the worst slaughter rampages of history, where 100,000 Jews died. Many remaining Jews fled to Spain, where in the course of time a golden age of scholarship unfolded. Kabbalism itself started to develop, making connections later with a revived Merkabah teaching. Again the writers ascribed what they had written to previous sages, and again they hid their work from all but the initiated. 
Some time between 1280 and 1286 a great event manifested itself. The scholar Moses de Leon was somehow or other vouchsafed the text of The Zohar, "Bar Yohai's own book," and he wrote it down. A fascinating conflict has raged about this event. Had there really been an actual book, The Zohar? Did Moses de Leon get hold of it to make his copy? Did he merely absorb the tradition from the Kabbalistic movement of the time? This latter must have been the case, say textual analysts, since Kabbalism, implicit in the theme of the book, did not exist in Bar Yohai's time. Did he simply sit at his desk and make it all up, as his wife seemed to believe? Or was the book produced by automatic writing as his friends in later ages say?

Dante purported to write down a dream; we have it in the three books of The Divine Comedy, a great deal of which has a dream quality, but maybe not all. The same applies to John Bunyan's Pilgrim's Progress; William Blake's prophetic books also emanate a shamanistic quality. From what level does this material come? When dealing with mystics it is hard to know who wrote their works, an "angel" from a different realm or previous age, or they themselves. Furthermore, the cosmology implicit in this kind of poetic production is a dynamic, hidden doctrine, a matter of the intuitive flash, "illuminating and disappearing as sunbeams play on the surface of the water," as Moses de Leon himself described The Zohar (The Zohar 1:4lb). On a mundane level, Kabbalism derived from the ancient texts of the time when Bar Yohai was the greatest saint, suggesting some kind of connection. Certainly all believed the book to be authored by Bar Yohai.

Spain was no permanent resting place for the Jews. The Inquisition began its cruel work, resulting in the expulsion of the Jews, many of whom migrated to Morocco and other parts of North Africa; others left for western Europe and various Mediterranean cities. These Sephardim (Spanish Jews) brought the Bar Yohai devotion with them. (The most important Jewish shrine in Morocco in recent times was the Moroccan "tomb" of Rabbi Shimon Bar Yohai, visited before the 1950s by 15,000 annually.) Of The Zohar itself there is little mention until the sixteenth century, when Isaac Luria, a German-born young man living in Cairo, met a man with a holy book that turned out to be The Zohar. Luria acquired it, and his life changed. He spread its fame everywhere, finally leading a new group of mystics to northern Galilee where he reestablished the community of Sefat. He became a saint; his title, Ari, meant "the lion." Many said he was the reem- 
bodiment of Bar Yohai himself, just as Bar Yohai was the reembodiment of Moses.

Now that The Zohar was found, it was printed (1558-60) and disseminated with astonishing rapidity all over the Diaspora. It was eagerly read and incorporated into much of Jewish thinking and ritual. In the Carpathian mountains, the Ba'al Shem Tov ("The Master of the Good Name"), the founder of Hasidism, on reading The Zohar said:

With the light created by God during the six days of Creation Adam could see from one end of the world to the other.

God hid the light away for the righteous in the hereafter.

Where did he hide it?

In the Torah.

So when I open The Book of Zohar, I see the whole world.

[Epigraph in 1983 edition of Moses de Leon, p. 2]

Hasidic tales relate that during the Ba'al Shem's nighttime studies this saintly scholar radiated a holy light (Levin 1932: 42-43). The Zohar grew in fame through the devotion of the followers of the Ba'al Shem Tov and that of the Hasids who lived all over northern Europe, where they faced much anti-Semitism. The Hasids and the Sephardim have been the book's greatest adherents, the Hasids being the principal scholars, and the Sephardim the divines, the chanters of the holy verses as a kind of ritual.

Centuries passed before the beginning of the aliya (the going-up), the return to Israel, the ingathering of the sparks. B'nai Brak, the Hasid "city of Holiness," was settled in Tel Aviv in 1924. During the Holocaust, scholar-mystics in Europe faced the unspeakable in persecution. But the tradition survived. After World War II the Hasids arrived in Israel and developed their communities; in B'nai Brak today The Zohar lives once again, still in private, to be sure, for only male elders are considered fit to read the sublime script. In 1955 Moroccan Jews, expelled by the Moroccan government in retaliation for the dispossession of Palestinian Arabs, were ingathered into Israel. The scene was set for a great revival of the cultus of Bar Yohai.

Viewing the history of this culture we see a curious pattern. It consists of much "looking back," in fact, writing books and ascribing one's words to the ancients-pseudepigraphy, Scholem calls it-a pattern that runs through both the Old and the New Testaments. I express the process by arrows in Figure 10.1. This process is important to the 


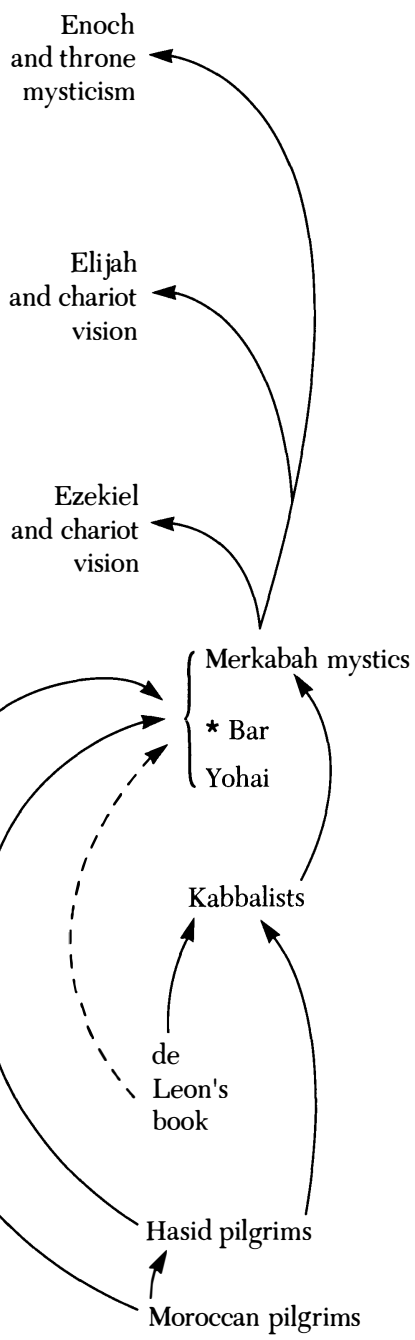

Figure 10.1. Looking backward: the links between pilgrims, mystics, and Bar Yohai.

formation of a creative persona and to his or her further development as an allegorical type. In this case, the Merkabah mystics, of whom Bar Yohai was clearly the principal, treasured in their secret lore"looked back to"-Ezekiel's chariot vision, Elijah and his chariot story, and Enoch, the angel Metatron. The Kabbalists later treasured the Merkabah mystics, deriving their visions from them. They too "looked back"; Moses de Leon in Spain used Kabbalism in writing The Zohar 
and ascribed authorship of his book to Bar Yohai, who lived much further back in time than the Kabbalists. The Hasids grew up on The Zohar; they too venerated Bar Yohai as its author. In the present age the Moroccan Jews, originally from Spain and now in Israel, look to the Hasids as their reference group, albeit with ambivalent feelings, and visit Bar Yohai's tomb in the hundreds of thousands for healing and enlightenment. Time's direction moves forward, but the present is busy creating the past.

Thus, Bar Yohai has been popularly sacralized as the hinge of all Jewish mysticism-constituting a strange story of performance and reperformance down the ages, but not a surprising one when the theme is mysticism. There may be vital cultures based on the most shadowy of protohistories. The pilgrimage is a kind of "restored behavior," Richard Schechner's term for

living behavior independent of the causal systems that brought them into existence; they have a life of their own. The original motivation of the behavior may be lost, ignored, or contradicted. How the strip of behavior was made, found, developed, may be unknown or covered over, elaborated, distorted by time. Originating as a process, it is used to make a new process-a performance. The strips of behavior are "material." Restored behavior offers to both individuals and groups the chance to rebecome what they once were or to rebecome what they never were. Restored behavior is "out there" symbolic, reflexive... and may be created from a distant place or an actual past. [Schechner 1983: 164, 166]

Schechner's diagram (1983: 167) may be adapted for the Bar Yohai pilgrimage and The Zohar; in Figure 10.2 I illustrate how the "nonevent" (in Schechner's terms) of Bar Yohai's authorship (one impossible to verify) is responsible for the pilgrimage to Bar Yohai. The event, the authoring by Moses de Leon, results in the restored event when the book is read. These two, non-event and event, are joined when a worthy pilgrim, that is, a mature male Hasid, studies it.

\section{The Doctrine}

I turn now to the actual Kabbalah (much of it deriving from Isaac Luria), since the devotion to Bar Yohai is basically related to its teaching. Here the Kabbalistic creation myth, which differs from that of 


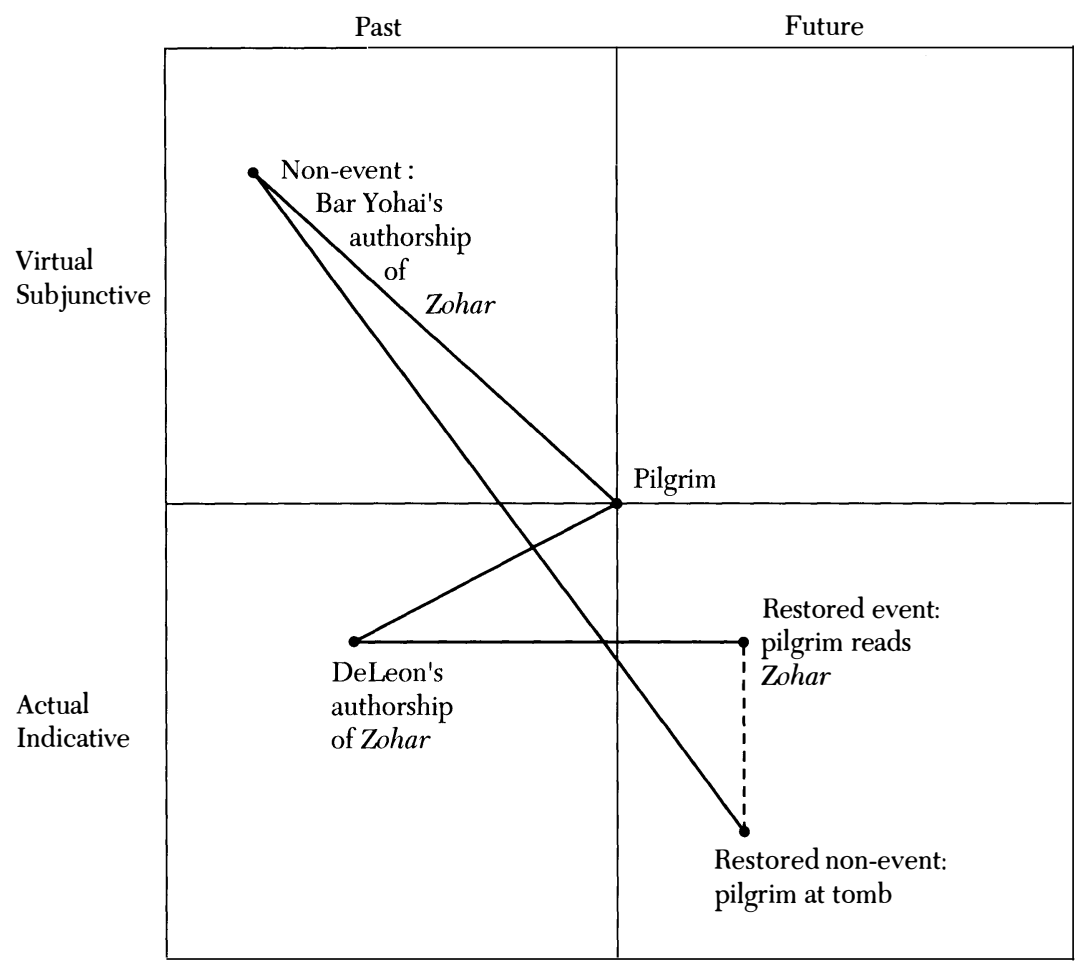

Figure 10.2. Pilgrimage and book as restored behavior.

traditional Judaism, is most relevant. To describe it, I use the words of Gershom Scholem (1961; see also Victor Turner's comments on this passage, 1985b):

The Midrash refers to God as having concentrated His Shekhinah, His divine presence, in the holy of holies, at the place of the cherubim, as though His whole power were concentrated and contracted in a single point. Here we have the origin of the term Tsimtsum [concentration], while the thing itself is the precise opposite of this idea: to the Kabbalist Tsimtsum does not mean the concentration of God at a point, but his retreat away from a point.

What does this mean? It means that the existence of the universe is made possible by a process of shrinkage in God. How can there be a world if God is everywhere? If God is "all in all," how can there be things which are not God? How can God create the world out of nothing if there is no nothing? This is the question. The solution became of the 


\section{Edith Turner}

highest importance in the history of later Kabbalistic thought. God was compelled to make room for the world by abandoning a region within Himself, a kind of mystical primordial space from which he withdrew in order to return to it in the act of creation and revelation. The first act of $E n$-Sof, the Infinite Being, is therefore not a step outside but a step inside, a movement of recoil, of falling back upon oneself, of withdrawing into oneself. Instead of emanation we have the opposite, contraction.

The first act of all is not an act of revelation but one of limitation. Only in the second act does God send out a ray of His light and begin his revelation, or rather his unfolding as God the Creator, in the primordial space of His own creation. More than that, every new act of emanation and manifestation is preceded by one of concentration and retraction. In other words, the cosmic process becomes two-fold. Every strain involves a double strain, that is, the light which streams back into God and that which flows out from Him, and but for this perpetual tension, this ever repeated effort with which God holds Himself back, nothing in this world would exist. There is fascinating power and profundity in this doctrine. [260-61]

There are two other important ideas in later Kabbalism. They are the doctrine of "the Breaking of the Vessels," and that of Tikkun, which means mending or restitution of a defect. The divine light which flowed into primordial space unfolded in various stages. It came to pass within a realm of existence called the Pleroma, or the "fullness" of divine light. The first being which emanated from the light was Adam Kadmon, the "primordial man." Adam Kadmon is the first configuration of the divine light which flows from the essence of En-Sof into the primeval space of the contraction. The lights of the Sefiroth, spheres of manifestation, burst from his eyes. It was necessary that these isolated lights should be caught and preserved in special vessels. But the light broke forth all at once and its impact broke and shattered the vessels. [265-66]

Thus there is no sphere of existence that is not full of holy sparks which are mixed up with the broken vessels and need to be separated from them and lifted up...the process of Tikkun, restoration. [280, 283]

The doctrine itself demonstrates in a curious way the actual longterm history of the root paradigm of Bar Yohai and the mystic tradition. We can mark the links of the root paradigm that produced not only Bar Yohai but his later redactors and the final efflorescence of the pilgrimage. One can follow the double strain of contraction and light 
as expressed in Judaic religious protohistory and in later action deriving from that protohistory. The double strain appears as a series of contractions alternating with experiences of light:

\begin{tabular}{|c|c|}
\hline Contraction: & the creation, including Adam Kadmon \\
\hline Light: & light from Adam Kadmon's eyes \\
\hline Contraction: & breaking of the vessels, scattering of the sparks \\
\hline Light: & the angel Metatron with his fiery torches \\
\hline Contraction: & slavery in Egypt (among many other episodes) \\
\hline Light: & Moses' burning bush \\
\hline Contraction: & the Babylonian captivity \\
\hline Light: & Ezekiel's chariot vision \\
\hline Contraction: & the Roman conquest \\
\hline Light: & $\begin{array}{l}\text { the experience and teaching of Bar Yohai and the } \\
\text { Merkabah mystics }\end{array}$ \\
\hline Contraction: & the hiding of the mystic books during the Diaspora \\
\hline Light: & The Zohar, The Book of Light \\
\hline Contraction: & the Spanish Inquisition; hiding of sacred books \\
\hline Light: & $\begin{array}{l}\text { the spread of The Zohar into the Diaspora; its effect } \\
\text { on the Ba'al Shem Tov }\end{array}$ \\
\hline Cont & anti-Semitism and the Holocaust \\
\hline Light & $\begin{array}{l}\text { the aliya, ingathering of the sparks, to Israel; the } \\
\text { pilgrimage to Bar Yohai's tomb }\end{array}$ \\
\hline
\end{tabular}

Victor Turner likened the empty point in the Kabbalah doctrine to the liminal phase in a rite of passage (1985b: 210). The implications are that in the process of the generation of creativity in any culture these empty points do exist, and are times that have to be filled, as a vacuum has to be filled. They are the times of "negative capability," as John Keats called them. In the process outlined above we see a prolonged oscillation throughout history between these two poles or "strains."

The light and its origin in the Shekhinah, the Divine Presence, are symbolized in one of Judaism's most emotional songs, the hymn greeting the Sabbath Queen, the female figure of the Shekhinah returning from her exile. It was composed by one of the later Kabbalists, Solomon Alkabez (Scholem 1965: 141), and begins, "Go, my beloved, to meet the bride / Let us receive the face of the Sabbath."

"On the Sabbath the light of the upper world burst[s] into the profane world" (Scholem 1965: 139) and is welcomed by the ceremony of Kabbolos Shabbos, when the congregation "turns westward on the Sabbath eve and bows to the approaching Bride." Scholem continues, 
"It is recorded that Luria, standing on a hill near Sfat, beheld in a vision the throngs of Sabbath-souls coming with the Sabbath-Bride. A strange twilight atmosphere made possible an almost complete identification of the Shekhinah, not only with the Queen of the Sabbath, but also with every Jewish housewife who celebrates the Sabbath. This is what gave this ritual its enormous popularity" (Scholem 1965: 14041). The symbolism of the lights (oil or candle flame) ritually lit by the mistress of the house on the Sabbath Eve is related to the same doctrine of light, the Zohar. The Kabbalah shows its influence all through Jewish life.

The ingathering of the sparks is an act that God is unable to accomplish alone. It is humanity's task, part of the oscillating process of contraction and expansion. From this primal charter derives much of the sense of task and mission that is the dynamic behind the Jewish religion, behind the growth of the mystical tradition, behind the survival of the Jews under later persecutions; it has been a great incentive for Zionism, the return of the Diaspora to its homeland. The promise "next year in Jerusalem" derives from the same source. One could compare the power of this primal charter with that of the Irish legend set in the fifth century A.D., which recounts how St. Patrick climbed Croagh Patrick Mountain and there maintained such a fierce ascetism that God himself was frightened and sent Gabriel to buy him off. Before St. Patrick would come down from the mountain he exacted four promises from God, one of which was that Ireland should be a united country. It is this legend that is behind the acts of the IRA in Belfast today.

Let us return to Bar Yohai sitting in his cave, contemplating, we suppose, the vision of God's throne and chariot. As noted, many of his devotees regard him as the reembodiment of Moses, and in the sixteenth century, Isaac Luria, the Ari and source of the later Kabbalah, was in his turn regarded as the reembodiment of Bar Yohai. Moshe Shokeid, describing his own participation with Moroccans in the pilgrimage of 1966, hinted that when a certain "old man of learning" came to his fire and asked to warm himself, Shokeid's Moroccan friend associated their visitor with the supernatural (Shokeid 1974: 82-83). The assumption was that it was Bar Yohai. On a visit to the tomb in 1980, I encountered an old Hasid in circumstances that suggested he was more than he appeared. The tradition is shot through with such connections, and they show how the creative persona seems to overstep time. Other noted examples of legends of the reembodi- 
ment or revisitation of a creative persona are King Arthur, "the once and future king," who, legend says, will return one day to lead the British; Sir Francis Drake, in a poem by Henry Newbolt, Drake's Drum; Bonnie Prince Charlie, for the Scots; Emilio Zapata for the Mexicans, said to come again to the villages of Morelos whenever peasants are oppressed; John F. Kennedy; Caitanya of India, who, during the Portuguese and Mogul invasions, was believed to be the avatar of Krishna; Jesus, believed by his followers to be the son or embodiment of God who will come again; and many more. What do they have in common? Boldness; living at a liminal time, in an era of discontinuity; charisma and the quality of the allegorical type; that is, each in his time represents and is identified with his suffering society, and is intensified by the retroactive shaping of that society. It is as if such personages were vouchsafed a repeated life: one life bursts its natural span and spreads into other lives, eventually flooding their successive environments with supernatural power.

The characteristics of a major creative persona begin to emerge. First, the identity of such a one may not be limited to his or her life span; it oversteps time and is thought to be reembodied later. Second, the era of the creative persona's life, the "heroic time," as Victor Turner called the date of an epic event (1985a: 98-103), is at some turning point in history, a time of discontinuity when the society is in the throes of change. Usually a maturation period intervenes, lasting until another liminal age when the society has again been shaken and is in need of answers to its dilemmas. At this time the resources of the past are tapped by gifted individuals, and the great teachings or events of the past may be written down. This is "narrative time" in Victor Turner's terminology. In the case of Bar Yohai the task was taken up by Moses de Leon in The Zohar. "Documentary time" occurs later, as when Isaac Luria and his band of scholars worked with large parts of The Zohar in redactions and recensions of the doctrine. Such an era includes the critical attacks of the historian Heinrich Graetz (1975) and the careful textual analysis of Gershom Scholem. And it includes the fundamentalist viewpoint of the earlier and later Hasidic scholars (who probably understood this school of mysticism best), producing new variants such as Martin Buber, Marc Chagall, Isaac Bashevis Singer, and influencing many others, such as Jacob Boehme, William Blake, and Patrick White (The Riders in the Chariot).

Thus, there are complicated connections between creative personas 
and liminality. The creative personas are dressed by society in allegorical robes; their new power supports their followers in future ages in their dark hours, and resupplies them with their sacra, the holy doctrines. Changes in the use of the doctrine also occur in liminal pockets. One may cite other examples. The Kebra Negast, the ancient text of Ethiopia, gives power to the Rastafarian movement and to reggae music in Jamaica today; the tale of the martyrdom of Hussein and its reenactment in Muharram is vitally important in contemporary Iranian politics; the biblical tale of Exodus was used in the U.S. civil rights movement as well as in the modern aliya to Israel.

The third characteristic of the creative persona is that of the "constellated individual." In psychology "constellation" refers to a group of related thoughts or feelings clustered around one central idea. A neo-Jungian psychologist, Anthony Stevens, made daring statements about the concept at the 1984 conference "Neurobiology, the Social Sciences, and Religion" sponsored by the Institute for Religion in an Age of Science. Stevens reminded us that in Jung's psychology of individuation the healer's aim is to produce a full "Self," that is, a creative persona. Jung shows the Self as an individual in a social setting, sharing an unblocked collective unconscious and consciousness with all humanity. It is a mystic's concept. Stevens equated this Self with "Anthropos," the gigantic figure of the Human, none other than Adam Kadmon, the Primal Man of the Kabbalists. But Stevens went further and identified this concept with "Gaia," meaning not only all humanity but the whole earth as one organism. The struggle toward this all-inclusive soul can be recognized in some of the creative personas in the essays in this book. At the conference Stevens described how "the Anthropos may come out as constellated by an individual human being. Later this may fall away and appear in another" (Stevens, personal communication). Put a different way, it is the collective archetypal "sense-of-itself" of a broad group, or even of the whole of humanity, emerging as a configuration in the personality of some highly conscious individual. Bar Yohai has been taken up by Sephardic and Hasidic Jewry as such a figure, transformed from a simple scholar to the epitome of Judaism, holy, luminous; The Zohar, the book of light and healing, in his hands (as he is pictured in the handouts at the tomb). Both the tomb of the saint and his book are reckoned to have healing power. And the book is undoubtedly the greatest spiritual book of the Jews after the Talmud. 


\section{The Pilgrimage: Background}

The pilgrimage to Meron demonstrates how deep may be the effect of an allegorical type on future generations. ${ }^{3}$ The old tomb of Bar Yohai in northern Galilee (never quite neglected, it seems) began to increase in popularity with the arrival of the Sephardic immigrants after 1955. Meron was a liminal shrine for a liminal people on a liminal occasion, celebrating the mystic, liminal branch of Judaism.

Each year the number of pilgrims at the yearly festival increases. The national bus company has taken over transportation, and police put up barriers to control the crowds. Every year a market appears by the main road, and a tent city materializes around the tomb. Inside the first and second courtyards of the tomb, barriers divide the space into two equal parts: one giving access for the ten thousand Hasids to the main hospice (including a private passage leading to the back of the tomb), and the other funneling over 200,000 Sephardim into the main tomb room. The central rabbinate in Jerusalem, representing law-minded, orthodox, and non-Hasidic Judaism, continually issues warnings on television and radio that men and women should not touch one another in the crowd, and that no menstruating women should approach the shrine. They also announce: "This is not a suitable event. Do not attend. There is bad slaughtering at Meron" (Haim Hazan and Judith Goldberg, personal communication). The rabbinate also forbids any hint of saints' worship, with minimal success. ${ }^{4}$

Neither Hasids nor Sephardim at the pilgrimage are politically sophisticated. To the Hasids on pilgrimage little is of any moment save the vision of God, while the Sephardim are far from being politically organized. ${ }^{5}$ This is a popular celebration, with a long history that shimmers through the events at various points.

\section{A Pilgrimage Narration}

In the following transcript I am my own informant, and give what this informant "dictated" to my notebook the day after the pilgrimage. My informant, a Catholic, had her own feelings, opinions, and biased religious attitudes.

I remember Lag B'Omer with great fondness-even the dust, heat, thirst - thirst that was quenched at the welcome steel faucets. So what 
is Meron? A turnoff near the northern border of Israel, where the territory ends among wild mountains and forests, dominated by the father of mountains, white-haired Hermon himself. Out on those foothills, lodged on the spurs overlooking Galilee, stand the holy villages of the mystics. From the heights of old, those bearded men, Bar Yohai, Rabbi Akiba, Rabbi Hillel, and later, the Ari, Moses Cordovero, Hayim Vital, and Solomon Alkabez stared upon the mists, forever drawing forward in their minds the threads of the even more ancient writings - the legends of angelic Enoch, Abraham's act, the Song of Songs, Ezekiel.

The greatest of the searchers, Shimon Bar Yohai, a little after Christ, began to write-so the folk tell us—-the great mystic book of the Zohar. No, this is untrue, say modern scholars, Moses de Leon wrote it a thousand years later. But where did de Leon, a relatively insignificant man, get the ideas? Bar Yohai wrote in his own tradition shortly before the regularizers of Christianity began to get busy building institutions and creating structural rules. This mystic, however, kept the faith so that later Christian mystics, the Rhinelanders, Boehme, and Blake, could light their tapers from his testament (or was it his?) of light. And just as in India when a holy man dies and the simple people feel his touch of mystic communion, perhaps more after his death than before, so the legends about Bar Yohai started, legends of healings, favors, even resurrections at his tomb.

It is said that the common people don't know anything about Bar Yohai's doctrine, they haven't been allowed to learn it, they don't care to, the shrine is merely a center for folk medicine or magic. There's no explaining why the folk hit on a certain saint. But how did this shrine hold the attention of many of the Jewish people from way back, all through the reign of the Dark Ages in the rest of Europe? Here at Meron the devotion must have been assisted by the coming and going of the ancient Jewish mystic sages between Sefat and Babylonia. The tomb then withstood Islam, how we do not know-while Palestine itself continued the decline begun by the Romans. But again thinkers and mystics returned to these northern rain-obscured heights in the sixteenth century, having brought back from Spain-where the "cabals" had gathered-the sacred Zohar. They were treasuring, under the old human law of anamnesis, what might one day save the human race.

And now under the burning ripe sky, we crowd up and up, walking with our fellow humans, stopping like them at some sideshow or 
gambling game, or Begin's election booth, plastered with signs saying, "Vote for the Freedom Party." Then comes a group of non-Hasidic ultra-orthodox on the left side of the road, displaying long blackthonged arm bands, tefillin, which they urge men to come forward and be bound with; then a loving couple walking entwined. Just opposite is an encampment, one of hundreds that have been set up by the path. A cheerful young Sephardi woman and her family are out by the wire fence with a young live sheep, which the small boy is petting. Our anthropologists passing by twit them about the pity of killing it. Sure enough, next day the family is proudly displaying its carcass that they've skinned and strung up for the passerby to admire. The family is going to invite the public in to share the meat.

Now, while Vic rests his arthritis for a moment in a folding chair, up through the crowd pushes a group of young people led by a singing woman and a young man with a drum. They clap and dance in a wide line, then pass on jovially. Now we proceed upward past an old Sephardi in a white jalabiya gown, selling blessings, and a couple of rascally beggars on the right, sitting comfortably on the ground with tin cans for money beside them. And at last we see in the crowd a group of young men in skull caps and ordinary clothes, toiling upward and singing. One of them bears in his arms a large object flowing with veils, topped with two crowned knobs. It is the Torah in Her silver case; they are bringing Her up to Her ark in the shrine. Men stop on seeing the group and come forward to kiss the Torah with great emotion, weeping. The Moroccans, now that they are here, need not fear oppression, their beloved and main unifier is with them like a sacrament.

A party of Hasids scissor past through the crowd, touching no one. They wear beards and sidelocks, black coats and black wide-brimmed hats. They stride purposefully, minds elsewhere, with hands turned back, the skin of their faces pale and pure. The crowd parts to give them room. We press upward, now passing an incense seller on the left who displays on the ground incense grains heaped in different colors, with medicines too, perhaps from the ancient Kabbalistic tomes-so far from sorcery really, this joyous crowd with its love of the zaddik, who was not just a law-rabbi, but a visionary. And the thrill is here in the crowd in the deep sun. The zaddik's holy picture is in everyone's hands. He is depicted bearing the scroll of The Zohar, and even I can read the title in the very holy Hebrew script. The germ of thrill, still small in us because we know so little, grows as we 
get pressed through the shrine doors and deposited finally at the rail of the little stone container of his body-nearly two millennia old.

Women are all around me; Rachel, a student, is by my side translating. Everyone feels excited-the women are on the point of dancing Moroccan style. One woman turns out to be weeping; she tells us she is barren, and if only the zaddik would send her a son she would name the child Shimon. Another, laughing, says, "I'm menstruating. Do you think they'll throw me out?" I answer via Rachel, "I don't mind, myself. I think you're lucky to be of childbearing age." One of them has many children, and we congratulate each other. We all proceed to throw candles into the tomb area-only I find I have thrown in the Easter candle I keep in my purse. Ah, well. There is a high drift of candles already accumulating in the tomb area. It would be impossible to light them here-the shrine would roast-but they pile up in white waxen innocence, saying love, flame, prayer. They will be used for bonfires on the roof.

The faces to my left are faces gone, gone into prayer and light and faith, round with the knowledge, "We are here," and with "Hear my prayer, Zaddik; if you grant that my child gets well I will come every year." I pray for my daughter, Irene, who is pregnant. I pray for the down-bearing power to be given to her older womb; how can we tell whether the instincts will be strong after thirty-five years? Her body needs to be fully used, with no Caesarean. ${ }^{6}$ Give her this grace, Zaddik, blessed are the givers.

Leaving the shrine I look for good camera stances, leaping about clumsily, never tired, pushing on, greeting strange women, hearing Brooklyn accents at one point-it is a Lubavitcher wife who has made the trip specially with her husband. We chat and get on a treat. I venture farther up the hill to the Sephardi market, where they sell holy oils for the fire, candles, fezes, and the like. I'm taken aback at a high black stall like a wall-it consists of tier upon tier of huge black volumes of The Zohar, on sale to the public. (The Zohar, like the tomb, will heal the sick and bring prosperity.) Three times I've asked passersby, "Do you read The Zohar?" And three times they've answered, "It's only for advanced scholars." But will this state of things continue with the books so easily available?

As Rachel and I pass the arches at the back of the shrine, we're offered paper plates of couscous by a man seated on the ground by the back entrance. The couscous is very welcome; in fact it's delicious. We offer him some arrack we have brought, which he accepts. A 
terrible noise breaks out from the barred compartments in the public hospice farther on. Two Moroccan woman are fighting over a sleeping place in it; they screech like dragon-sized petulant peacocks in a wild crescendo of barbwire sound. Alarmed relatives gather and try to separate them; one contestant pulls the other's bedding away and throws it out, the other grabs it back, battering bodily against her foe. Will it subside? We pass on like Dante and Virgil, with bowed heads.

Then to the long avenues of tents where I found peace and comfort everywhere, some of the tents with portable television sets, some with electric generators costing $\$ 4,000$, stoves, water pails, huge vacuum flasks of chilled drinks, carpets on the tent floors, wall hangings consisting of romantic velvet paintings, national flags everywhere, pictures of Bar Yohai, photographs of Navon, David Levi, Arik, Herzl, and Begin, political leaders and founders of Israel. And here the children play with wide eyes, as happy as if they were on the beach. The big fig tree by the caves, which exudes sap like mother's milk, is covered with tags of cloth. (Crapanzano 1973:80 describes the same among the Berbers). "Give us babies," is what the tags say. The grand instinct goes on. It'll stop with a jerk when the economic crash arrives and hurts the people-as history has shown before. But for now! This is what their presence tells us: "There's glory. We have the strength of numbers, the voting power, it's our country and we could make Israel into a more blissful Morocco, as long as we have jobs, schools, and a synagogue. Our religion's favored, there's no anti-Semitism; we all turn to Bar Yohai. But we don't rejoice in our sons being far away and in danger. No." I saw the awe and stillness in their eyes when they spoke of their sons in the army. These people weren't saber-rattling, they were, as I would put it, "keeping their fingers crossed."

Inside one reception tent, the table was exquisitely laid with lace and a silver tea service. The lady of the tent house leaned over and poured out tea for us. Her husband is a sanitary engineer in Tel Aviv; they're originally from Morocco. They complained to us about the Hasids. "We're gentiles to them, yet we keep the Sabbath like they do. Although they all wear black and get called 'the blacks,' they're 'whites,' and they treat us like blacks." A little old woman said, "They poured garbage on top of us from up there" (pointing to the Hasid yeshiva building). "They don't think we're human." "And the Hasids are mean," said the tent lady. "They charge us a lot for blessings." "That's a shame," I said.

In one tent a young Moroccan family had meat to offer and we 
stopped by. They complained about the Hasids like the others, but when a party of Hasids passed behind the tent they were happy enough to comply with our suggestion to ask them in for a chat. We wanted to talk about The Zohar but the Hasids refused, saying they were too young. But they entertained us all by telling Hasidic tales of Bar Yohai in his early days.

The Hasids said, "How do you Moroccans enjoy yourselves, living for a week outside? Never mind, we all have a Jewish heart." The Sephardim said, "You Hasids are the true believers, not like us. Look how you pray, dancing in a ring. We're only interested in food."

As Barbara Myerhoff, Vic, and I drew near one tent we found that the family had collected a Yemenite, a Spaniard, a German, an Algerian, and were now delighted to add an American, a Scotsman, and an Englishwoman. The father put on his white jalabiya robe and fez, and his wife danced to the tape recorder, swaying like a temptress in her long brocade gown. I danced, too-I was reminded of the African belly dance. This wasn't the world of sin and resistance to temptation. The wife was dancing for her guests with her husband's approval, simply enjoying herself. Barbara talked to the Spaniard in his own language.

Night had fallen and the moon was full: it was now time for the people to light the bonfires on the flat roof. There would be two barrels, each with a fire, one on the Sephardi side of the roof and one on the Hasids' (the separation of these groups remained strict throughout, save for that one meeting when we heard the Hasidic tales). The light of the fires was the "Splendor," the light of the Zohar itself.

We ascended the stairs and penetrated through the crowd to the Hasids' barrel. This turned out to be a wide-rimmed, upright concrete cylinder, about twice the size of an oil drum, set on a wide concrete dish to catch burning debris. It looked phallic somehow. It was surrounded by a group of Hasids who were mounting it up with fuel, candles mainly, and papers on which were written the name of the devotee, his or her mother's name (proving that he or she was a Jew), a request, and a prayer. The crowd of Hasids gradually thickened around the barrel, many wearing shtreimel, fur hats, some with vodka bottles protruding from their pockets. Singing began and circling dances, like a great pot slowly boiling. They were all touching one another in ecstasy. A tiny rebbe with an ancient white splayed beard approached, which he was only enabled to do by dint of the elbow work of stalwart young Hasids who fought outward against their com- 
rades to allow their elder to pass. Was he going to light the fire? A flash in the darkness-and a great shout as the first flames shot up, and grew, and grew. They fed it candles and emptied into it bottles of holy oil, then laid on an entire capote garment, folded-sacrificed on this altar. I saw arms silhouetted against the flame, pouring oil. ${ }^{7}$ The roof was one mass of black coats, hats, and pale faces; voices shouted "Bar Yohoi!" in harsh song-all the men moving and moving in a chain embrace until they were in trance. The dawn at the end of night would be the Shekhinah, the glory of God. As for me, I was perched up on the dome itself, while Vic and the others were shoved farther and farther away across the crowd until they reached the edge of the roof where there was a wire fence. Here Henry Abramovitch took up Vic's folding chair and fended off the crowd with it. Earlier Vic had been found resting his arthritis in that chair by the front entrance of the shrine, chatting to beggar women and, so he said, putting out his own hand with theirs every now and then, saying "Tsadaka, alms. Pity the poor anthropologist."

We managed to make our way down from the roof to gather at the cafe. Barbara and I told the others how nobody had stopped us climbing on the dome; the boys up there with their black clothes, fresh blooming faces, skull caps, and long ringlets, made way for us. "Though we took their places, they let us," said Barbara. "The communitas paradigm reigned." At the cafe we eagerly devoured lamb in pocket bread, the meat hardly cooked and still warm from the slaughtering, helped down with lots of hot sauce along with beer to quench our thirst. We rested, listening to the eastern music.

The obverse of the sublime on the roof was the official slaughter yard, situated some way beyond the shrine. Here a man in a white shirt, black pants, and skullcap gutted a sheep and skinned it. Another sheep lay on the ground with its throat cut but not yet butchered. A couple of rabbis stood by to perform the koshering, along with a couple of workmen. Half a dozen of the ordinary public hung around. The floor was concrete with long drains, where feces and blood were being washed down with hoses. High rails were slung with carcasses, all stamped "RABBI KOSHERED." Three cows lay nearby, sleeping.

We left the spot, determined to finish for the night. But far down toward the parking lot, one single tent was still in action. Around a tall fire sat a group of hippies, one with a cowboy hat; they were drumming and singing, so that we could not resist their invitation to join in. Barbara started making friends, and after a bit she turned to 
us and said, "You go on to bed, I'm staying up all night." The anthropologist in her was hooked.

\section{The Haircutting}

Here in the context of the Bar Yohai pilgrimage, three-year-old Hasid children were to be initiated by the cutting of their hair. Up to this time they had been "angels," now they would belong to the earthly world.

Up and down the rails dividing the courtyard of the shrine the Hasid wives pressed and craned toward their husbands and children on the sacred side-never shouting, but showing in their faces the strong will, the mild yet frightening persistence I had seen before. They wore the mandatory wigs, headscarves, long-sleeved dresses, stockings, and shoes of ultra-orthodox women. Their faces were not really with us; they were watching the scene beyond, where their children moved above the crowd of black coats and hats, perched on their fathers' shoulders. The innocent overblown pink little faces—overblown with tears in one case-were girlish faces, crowned with beautiful long hair tied on each side with pretty spangled bands, leaving the front hair curly and free. They clung affectionately to their fathers as they faced this way and that, borne in the dance to the sound of music. I was impressed at first how well the fathers were looking after their little daughters. Where were the sons, though? They were supposed to be so important. Then I noticed that every one of the "girls" was wearing pants, as well as an embroidered skull cap. These were the sons.

Someone put up a pair of scissors by a child's head and snip, the tress on one side was gone, leaving the curls in front to develop as side locks. The hair was taken away to be added to the furnace on the roof, destined for the angelic light. The boy was whirled on in the dance, displaying one side cut. When next I saw him, the cutting was completed, and his father had placed on his head his own huge shtreimel, under which the child labored, comforted only by a pacifier stuck in his mouth. He was now a real male, no longer just like his sister and belonging to the mother's world. Now that the traditional time of mourning, between Passover and Shavuot, was in abeyance, his hair could be ritually cut and he could celebrate his new membership of the holy Hasids while at the shrine of light. A collective celebration often triggers off individual ones. 
Now the boy would be ready for the Torah. His father would gradually teach him the holy letters, and the long specialization would begin, a training such as is hardly to be found on this globe. He would advance to the stage of Bar Mitzvah, when the wise boy, like the boy Christ in the Temple, would admonish us all, reading from the Great Scroll. He would proceed to long years of studying, sharpening and deepening the brain-weapon, then on to princehood in the courts of his Rebbe father, pointed out as a future rebbe, his clothes perfect. He would celebrate the festivals in collective groups, dancing in the synagogue, waiting in chastity. His marriage would be ordained by the rebbe: the bridegroom now trapped into the polluting if pleasurable task of fathering sons, and the wife keeping the home pure and kosher. And thus to the stage of fatherhood himself, involved with his son's bris (circumcision) - the son as a toddler wheeled about by the father in a pushchair among his other great progeny, all dressed in holy clothes. And the father, growing to middle age, in some business, handling papers with practiced efficiency, slapping them here, slapping them there, neatly pocketing pen and glasses. The yet older, knowing father in his huge shtreimel and huge beard at his son's wedding, teasing him, using solemn, witty words with hidden meanings, slipping sly smiles, making big gestures, continuing for seven evenings after the wedding at the feast at the end of each day of prayer. Or perhaps he would follow the more solemn route, the holier, that of the rebbe-consulted privately by husbands bearing little cloths from their wives to prove clearness from blood. The endless exegesis of the Book, the growing holiness, surrounded by reverent juniors, his beard now white, shoulders bent, the marvelous visage long and wrinkled, the ancient book under his arm. He has endured a life of study. Will not his prayers eventually prevail against God's wild and unwise creation, prayers in a life of perfection greater than anything God could have invented? Maybe the rebbe doesn't know what's good for us all, certainly we don't. But the man is a searcher.

So I press to the rail watching the slow swirl, the cram of "blacks" in front of me, and behind, the constant pushing drift of Sephardim into the shrine of the tomb.

What was not part of my own observations was an altercation on the roof later in the night of the bonfire, toward sunrise. Yoram Bilu reported that a large group of neo-Kabbalists, whose title is "Those Who Return to God in Repentance," went up to the roof to "bring in 
the Light." This was a young group from the city, unrelated to the traditional Hasid world community, mainly concerned during the last decade with reading and explaining The Zohar. They had women with them on the roof in an outer circle. Their rabbi was reading from The Zohar and interpreting it to the group. The Hasids began to that the neo-Kabbalists were too young and should not read The Zohar until they were over forty, and that women were wrongly hearing it, too. An argument began; the Hasids reportedly became violent and started a fisticuff fight. In an instant the police were on the spot and put a cordon between the two groups. Peace was restored by expelling the neo-Kabbalists.

Here the contradiction between the dominant symbol of Kabbalism, light, and its traditional milieu, secrecy, was brought out into the open. The Zohar should be, as in the Western hymn, "in light inaccessible hid from our eyes." Victor Turner, who held intensive oneto-one conversations with several Kabbalists ${ }^{8}$ during our stay in Israel, said, "The fire on the roof, the full moon, the dawn, and The Zohar, all are symbols of light, the Splendor, and mean the Shekhinah, the presence of God. If these are made too cognitive, it is a bad thing." So the Moroccan women themselves in the tomb room throwing unlighted candles symbolize the hidden nature of the Splendor, supplying by an indirect act, not an interpretation, what is needed to create the fire which can be seen for miles around. As we have seen, the Jewish housewife herself becomes the Shekhinah on the Sabbath, in the eyes of Kabbalists. (It is to be noted here that the Hasids' argument is not merely a matter of antifeminist prejudice.)

As for the full moon, of which we were very conscious during the pilgrimage, it too has a strong association with the Shekhinah. The Shekhinah, a bride and a queen, is often in exile. The lessening of the moon is a symbol of the Shekhinah's exile. The Shekhinah herself is the "holy moon." In redemption the moon would be restored to its original state (Scholem 1965: 151-52).

Thus, the light symbolism ought to come into consciousness by a back way, not through exegesis given openly at the shrine but through kinetic knowledge (probably via the limbic system of the brain into right-hemisphere consciousness, the nonexegetic but metaphoric one-to use the terms of modern neurobiology). The symbolism of the ingathering of the sparks was indeed shown at Meron. The pilgrimage looked at as a whole was the means whereby Hasids and 


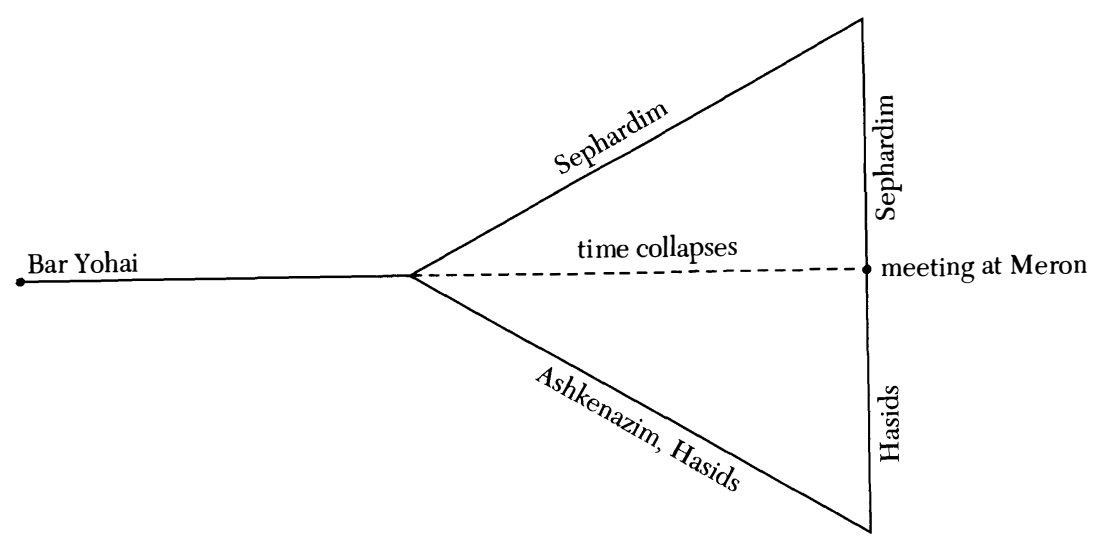

Figure 10.3. The ingathering of the sparks.

Sephardim met in propinquity, certainly closer than on any other occasion in conflict-ridden Israel. Their origins were so diverse, from northeastern Europe to Morocco on the southeastern end of the Mediterranean, that this was an extraordinary event. Figure 10.3 expresses it schematically.

So Bar Yohai and his book, The Zohar, have survived the obstacles of history into our own turbulent age. He points beyond us to the still hidden world of mystical enlightenment. He was a person who made himself into a "Self" (in Jungian terms) as a scholar of unusual gifts and one who went through the process of being created as a constellated individual by his own society as well as later ones. His virtue as a creative persona caused him to accrete to himself the allegories and root paradigms (in Victor Turner's sense) of former days; later ages built legend and allegory upon him. He cannot now be known for what he actually was in his day; his life is a "non-event," a life inextricable now from what later ages have done to it. Thus, to encompass the creative persona, we have had to follow his larger persona into the diachronic dimension, to examine the way liminal historical events have intensified the impetus and power of his persona. We have had to mark the response of society to its own creation, and to observe, if only partly, both the consciousness and the unconscious of that society (Myerhoff, this volume; Abramovitch and Bilu n.d.).

Why does society produce these rare individuals who pass through the nets of the statisticians, and have such fundamental effects on 
humankind for thousands of years? Such figures intrigue me greatly, and I am speculating that there may be a natural, providential supply of them produced by society just as the body produces antitoxins and endorphins to ensure survival and creativity. Furthermore, what "Bar Yohai" is effecting seems to be something we have not properly analyzed yet - it exists whether we understand it or not; there is anamnesis involved. We shall not know, until future events show us, how important such figures are.

\section{Notes}

1. There is a difference between the symbolic type (Handelman 1981) and the allegorical type (Lavie 1986). The symbolic type more often appears in actual rites of passage, in which it frequently enters as a clown figure; it is not a historic personage. Someone enacts the role. Both types mediate among the inconsistencies of the transitional social situation, but the symbolic type brings about the necessary changes without apparently effective or moral action. It acts like a catalyst. The allegorical type is more intrinsically concerned in his or her role, growing into it, as it were; the role is also shaped with meaning by society. He or she gives leadership, whether by the ability to hold up to society a picture of itself as it is or as it was in some previous golden age, or to point beyond all to a mystic, unifying vision.

2. These were Henry Abramovitch, Batsheva (a Hebrew University anthropology student), Yoram Bilu, Yoram Bilu's assistant, Yair Boni, Shifra Epstein, Harvey Goldberg, Richard Hecht, Barbara Myerhoff, Norit Ramon, Rachel Rosen, Norman Stillman, Yedida Stillman, and Shalva Weil. I gratefully acknowledge their valuable assistance and information.

3. In order to understand the modern context and root this essay on spirituality in reality, it is necessary to show a little of the political and community structure of Israel after immigration and war. In 1955, after the Moroccan government expelled the Jews in what has been called the Moroccan "holocaust," the labor government of Israel invited the refugees to Israel. Burdened with an austerity budget and a severe housing shortage, the government was hard put to resettle the vast numbers of immigrants. The existing, small kibbutzim and moshav farms were progressing well, run by internally democratic groups of educated Ashkenazim from Europe. But few were either able or willing to invite large numbers of Moroccans to share their lives. So the labor government set about building "development" towns on unoccupied land and on newly occupied and possessed territory in the northern and southern peripheries, often consisting of barren hills and desert. Some Moroccans were settled near Jerusalem. In 1983 I saw various settlements in southern Israel sited in strategic positions like fortresses along hilltops, far from sources of employment. There was a dead atmosphere in many of them, for unemployment was rife and many were on welfare. Owing to their negative feelings about the secularist labor party who, one might suppose, would favor this new working class, and because of their own political background, the Moroccans and other North Africans generally espoused the cause of the Likud, Begin's conservative party. Eventually, some found blue-collar jobs in Tel Aviv and elsewhere 
and began to grow prosperous, enriching Israel's popular culture with their festivals, music, dancing, sense of enjoyment of life, and their value set on hospitality.

4. The central rabbinate, the most powerful branch of Judaism, derived its teaching from the Torah, the biblical books of the law, rather than the Kabbalah. It sought to control the Sephardim's religion, but many of the Sephardim shrugged off the directives. The festival of Bar Yohai was the high spot of the year for the Sephardim, much as the carnival and Umbanda are focuses for black Brazilians in Rio de Janeiro-also a large population without much political development but a high sense of ritual and festival.

5. The account that follows gives examples of bad feeling expressed by Sephardic pilgrims, particularly complaints against the Hasids. Obviously the Sephardic accommodation at the pilgrimage center was not catered for like that of the Hasids, who were Northern Europeans. The Sephardim are labeled "primitive" by the law-minded orthodox, who stay home at pilgrimage time, considering the rite of candle-throwing to be pagan. In Israel the sophisticated are often in the labor party, a somewhat secular group that largely disapproves of the Meron pilgrimage and complains of the Moroccans' political backwardness. This is not the place to draw conclusions about Israeli politics, merely to show "the predicament of homecoming" for the Moroccans, as Deshen and Shokeid (1974) termed their condition in their study of the North African Jews in Israel.

6. Oddly enough little Rose was born prematurely, just when we returned from Israel. Bar Yohai was overdoing it a little.

7. At the 1984 pilgrimage to Meron the following year the fire spilled over the rim of the barrel and set the roof itself ablaze, causing considerable damage.

8. Mordechai Rotenberg, Eliezar Goldman, Moshe Idel, and Professor Halamish.

\section{REFERENCES}

Abramovitch, Henry. n.d. "Sacred Shrines and Holy Chance: Two Pilgrimages in Northern Israel." Typescript written for the Sackler School of Medicine, University of Tel Aviv.

Abramovitch, Henry, and Yoram Bilu. n.d. "Dreams of the Pilgrimage: In Search of the Saint." Typescript written for the Sackler School of Medicine, University of Tel Aviv.

Crapanzano, Vincent. 1973. The Hamadsha. Berkeley: University of California Press.

Deshen, Schlomo, and Moshe Shokeid. 1974. The Predicament of Homecoming: Cultural and Social Life of North African Immigrants in Israel. Ithaca: Cornell University Press.

Graetz, Heinrich. 1975. The Structure of Jewish History. Trans., ed., and introd. by Isman Schorsch. New York: Jewish Theological Seminary.

Handelman, Don. 1981. "The Ritual Clown: Attributes and Affinities." Anthropos 76, 1/2: 321-70.

Handelman, Don, and Bruce Kapferer. 1980. "Symbolic Types, Mediation, and the Transformation of Ritual Context: Sinhalese Demons and Tewa Clowns." Semiotica 30, 1/2: 41-71.

Lavie, Smadar. 1986. “The Poetics of Politics: An Allegory of Bedouin Identity.” 


\section{Edith Turner}

In Myron J. Aronoff, ed., Political Anthropology, vol. 5, The Frailty of Authority. New Brunswick, N.J.: Transaction Books. Pp. 131-46.

Levin, Meyer. 1975 [1932]. Classic Hasidic Tales. New York: Penguin Books.

Moses de Leon. 1983 [1280-86]. Zohar: The Book of Enlightenment. Trans. with introd. by Daniel Chanan Matt. New York: Paulist Press.

Schechner, Richard. 1983. Performative Circumstances from the Avant Garde to Ramlila. Calcutta: Seagull Books.

1985. Between Theatre and Anthropology. Philadelphia: University of Pennsylvania Press.

Scholem, Gershom. 1961. Major Trends in Jewish Mysticism. New York: Schocken.

- 1963. Introduction to Zohar, The Book of Splendor: Basic Readings from the Kabbalah. New York: Schocken.

- 1965. On the Kabbalah and Its Symbolism. London: Kegan Paul.

Shokeid, Moshe. 1974. “An Anthropological Perspective on Ascetic Behavior and Change." In Deshen and Shokeid 1974.

Stevens, Anthony. 1982. Archetype: A Natural History of the Self. New York: Morrow.

Turner, Victor. 1985a. On the Edge of the Bush: Anthropology as Experience. Tucson: University of Arizona Press.

—. 1985b. "Liminality, Kabbalah, and the Media." Religion 15: 205-17. 